\title{
IDENTIFIKASI AWAL SITUS MASA KLASIK DI LEUWILIANG KABUPATEN BOGOR
}

\author{
Preliminary Identification of Classical Site in Leuwiliang Bogor
}

\author{
Rusyanti \\ Balai Arkeologi Jawa Barat \\ Jl. Raya Cinunuk KM.17 Cileunyi 40623 \\ E-mail: rusyanti08@gmail.com
}

Naskah diterima: 27 September 2019 Revisi terakhir: 11 November 2019

Disetujui terbit: 05 Desember 2019 - Tersedia secara online: 17 Desember 2019

\begin{abstract}
Bogor is a location that belongs to the influence of the Sunda kingdom in the past. This area is often found the remains of the past that are suspected as archaeological artifacts, one of which is a report of urns findings in the Barengkok village in Leuwiliang District, Bogor Regency. To confirm the findings, the West Java Archaeological center conducted preliminary research and field surveys. The results indicated that the findings of the objects inside the jar are of ceramic fragments, pottery and metals allegedly were collectible items that were deliberately placed in a jar and then buried, the burial purpose is yet unknown because the remains are not associated with other findings although the location of the findings still has a chance to contain archeological potential since the classical sites in Indonesia is often adjacent to the river, on high land and or elevated and oriented to mountains or high places. Advanced research and test pit is a preliminary recommendation that can be done at a later stage.
\end{abstract}

Keywords: Bogor, Leuwiliang, the Jar findings.

\begin{abstract}
Abstrak
Bogor merupakan lokasi yang termasuk ke dalam pengaruh Kerajaan Sunda pada masa lampau. Wilayah ini seringkali ditemukan tinggalan masa lampau yang diduga artefak arkeologis, salah satunya laporan tentang temuan guci di Desa Barengkok Kecamatan Leuwiliang, Kabupaten Bogor. Untuk mengkonfirmasi temuan tersebut Balai Arkeologi Jawa Barat melakukan penelitian pendahuluan dan survei lapangan. Hasil penelitian mengindikasikan bahwa temuan benda-benda di dalam guci berupa fragmen keramik, tembikar dan logam diduga merupakan barang-barang koleksi yang sengaja diletakkan di dalam guci dan lalu dikuburkan. Belum diketahui maksud dari penguburan tersebut karena tinggalan tersebut tidak berasosiasi dengan temuan lain meskipun area lokasi temuan masih berpeluang mengandung potensi arkeologis mengingat bentukan lahan situs masa klasik di Indonesia seringkali berada berdekatan dengan sungai, di lahan yang tinggi dan atau yang ditinggikan dan berorientasi pada gunung atau tempat yang tinggi. Penelitian lanjutan dan test pit merupakan rekomendasi awal yang dapat dilakukan pada tahap selanjutnya.
\end{abstract}

Kata Kunci: Bogor, Leuwiliang, temuan guci.

\section{PENDAHULUAN}

Secara geografis wilayah Kabupaten Bogor berupa pegunungan dan dataran rendah. Struktur tanah pada umumnya merupakan tanah regosol dan latosol dengan 
curah hujan 2500 sampai $5000 \mathrm{~mm}$ pertahun. Geologi wilayah Leuwiliang (termasuk juga Ciampea) termasuk ke dalam fisiografi Zona Bogor dengan satuan geomorfologi yaitu satuan pungungan homoklin, satuan perbukitan lipatan, dan satuan dataran rendah dengan pola sungai dendritik, subdendritik dan aluvial. Struktur yang berkembang di wilayah ini adalah berupa sesar naik dan sesar geser yang berarah timur laut yang terjadi akibat proses tektonik pada Miosen akhir hingga plistosen awal. Stratigrafi wilayah ini terbagi menjadi 6 satuan batuan, yaitu batu lempung, batu gamping, tuff, Batupasir, Breksi, intrusi andesit dan breksi laharik (Nurwani Citra, 2010)

Di Kabupaten Bogor terdapat 6 (enam) daerah aliran sungai (DAS) besar yang memilki cabang-cabang hingga 339, yaitu meliputi DAS Cisadane, Ciliwung, Cidurian, Cimanceuri, Angke dan Citarum. Penelitian dilakukan di Desa Barengkok, Kecamatan Leuwiliang Kabupaten Bogor. Desa Barengkok terletak pada koordinat 6 $35^{\prime} 00^{\prime \prime L S ~-~}$ $6^{\circ} 36^{\prime} 30^{\prime \prime} \mathrm{LS}$ dan $106^{\circ} 38^{\prime} 00^{\prime \prime B T}-106^{\circ} 39^{\prime} 00^{\prime \prime} B \mathrm{BT}$. Luas desa Barengkok adalah \pm 450 Ha. Desa Barengkok secara administratif terbagi menjadi 10 Kampung yaitu Bantarung, Barengkok Satu, Barengkok Dua, Dahu, Cibata, Citeureup satu, Citeureup Dua, Kandang Sapi, Kampung Sakinah, dan Geledug. Batas desa barengkok sebelah Utara Desa Leuwi Mekar, sebelah Timur Desa Situ Ilir/Kali Cianten sebelah Selatan Desa Karacak dan sebelah Barat Desa Cibeber II (Simamora, 2013: 17). Lokasi penelitian berada di sebelah selatan desa berdekatan dengan Ci Teureup (Gambar 1).

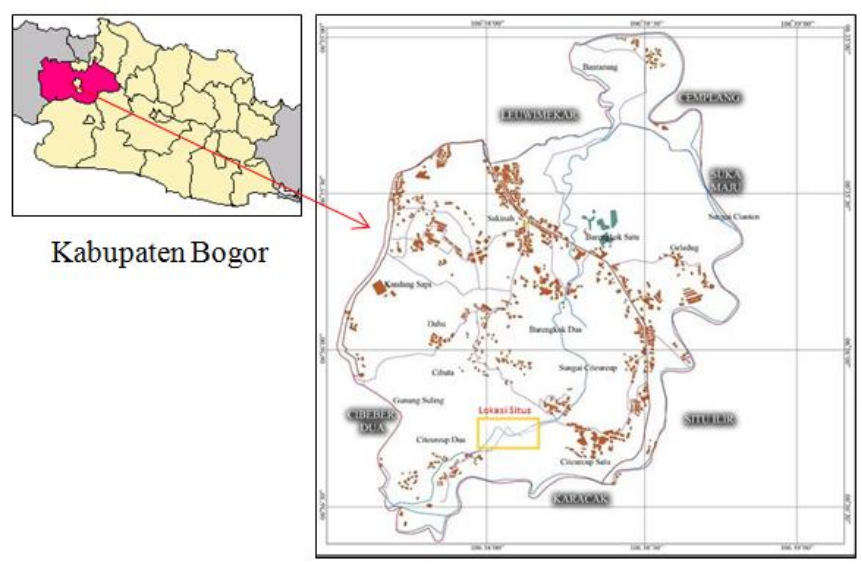

Gambar 1. Peta Desa Barengkok. Lokasi temuan arkeologis berwarna kuning. (Sumber Peta: Simamora, 2013: 18, dengan penyesuaian)

\section{HASIL PENINJAUAN DAN PEMBAHASAN}

Pada bulan Maret tahun 2018 di Desa Barengkok, Kampung Citeureup 2 ditemukan satu guci yang tersingkap $20 \mathrm{~cm}$ dari tanah ketika hendak ditanam mentimun. Lokasi temuan guci berada sekitar dua ratus meter di sebelah barat rumah Bapak Ace (pemilik lahan). Di dalam guci terdapat benda-benda kuno dari logam seperti genta pendeta, bagian timbangan yang sudah patah, wadah logam, dan bagian rantai pengait. Temuan temuan tersebut berada pada lahan di tengah sawah dan berdekatan dengan sungai.

Karakteristik tinggalan dan lokasi temuan di Desa Leuwiliang perlu untuk 
identifikasi aspek kearkeologiannya. Dengan melakukan survei arkeologi, pengamatan lingkungan, dan analisis artefak serta analisis kontekstualnya, tulisan ini berupaya melakukan identifikasi awal mengenai potensi kepurbakalaan masa klasik yang kemungkinan menjangkau wilayah Leuwiliang.

Sumber-sumber arkeologi masa klasik di wilayah Bogor setidaknya akan mengacu pada kerajaan tertua di Jawa Barat, yaitu Kerajaan Tarumanegara dan situs arkeologi terdekat, yaitu temuan struktur batu di Ciaruteun Ilir, Ciampea. Tinggalan Tarumanegara yaitu Prasasti Ciaruteun, Prasasti Pasir Kolengkak, Prasasti Kebon Kopi, Prasasti Pasir Awi, dan Prasasti Muara Cianten merupakan bukti pernah hadirnya pengaruh luar yang datang ke Nusantara pada kisaran abad ke-5 M yang membawa unsur keagamaan yaitu Hindu Veda berdasarkan dewa yang disebut dalam prasasti yaitu Wisnu dan munculnya peran kaum Brahmana yang melakukan selamatan (Poesponegoro, 1993: 38-39).

Selain temuan prasasti yang berkaitan dengan Kerajaan Tarumanegara di atas, ditemukan pula temuan struktur dari tatanan batu di Desa Ciaruteun Ilir, Kabupaten Bogor, yang terindikasi berasal dari masa klasik. Temuan struktur batu tersebut telah diteliti oleh Balai Arkeologi Jawa Barat pada tahun 2006, 2009, 2008, dan 2010. Penggalian yang dilakukan di situs Kampung Muara menghasilkan temuan berupa struktur batu yang membentuk lantai. Struktur batu tersebut pada beberapa bagian bersusun sehingga terlihat seperti pagar atau batas lahan. Adanya struktur batu tersebut menunjukkan bahwa di lokasi tersebut terdapat suatu pemukiman. Selain struktur batu, adanya pemukiman di situs Kampung Muara juga ditunjukkan dengan adanya sejumlah temuan artefaktual berupa fragmen tembikar dan keramik. Fragmen keramik yang ditemukan di situs Kampung Muara menunjukkan berasal dari China, Thailand, Jepang, dan Eropa. Fragmen tembikar dan keramik yang ditemukan di daerah ini sebagian besar berasal dari bentuk wadah yang digunakan untuk keperluan sehari-hari, seperti mangkuk, piring, guci, dan pot (Widyastuti, 2010)

Secara geografis lokasi Ciampea dan Leuwiliang berada dalam satu kawasan dengan bentang alam yang sama, yaitu pada dataran rendah di sebelah utara Gunung Salak dan dilewati oleh aliran sungai. Wilayah Ciampea dialiri Ci Aruteun, Ci Anten, dan Ci Sadane sementara wilayah Leuwiliang dialiri oleh Ci Teurep, anak Ci Anten. Hasil-hasil penelitian mengenai sebaran situs-situs arkeologi di Indonesia, pada umumnya mempunyai pola yang hampir sama, yaitu berkaitan dengan gunung dan sungai. Dua lokasi ini selain menyimpan potensi alam sebagai sumber kehidupan, juga menjadi orientasi kesakralan dan spiritualitas masyarakat pada masa lampau, sepertihalnya yang terlihat pada tata letak candi-candi di Jawa Tengah (Mundardjito, 2002). Berdasarkan pengamatan bentang lahan temuan guci di Desa Barengkok Kecamatan Leuwiliang karakteristik lahan dikelilingi bukit dan dialiri sungai, juga tampak di situs ini meskipun jejak-jejak arkeologis lainnya di wilayah ini tidak banyak.

Lokasi temuan guci berada pada lahan dengan pemandangan sekitar berupa perbukitan (Gambar 2). Aliran air berada pada area utara, melintasi daerah ini dari barat ke timur (Gambar 3). Lokasi guci berada pada lahan yang lebih tinggi di antara lahan 
lainnya. Pada tepian lahan ini terdapat tatanan batu yang membatasi lahan garapan. Di area barat disebutkan merupakan lokasi temuan bata. Pada saat peninjauan lahan ini tertutup tanah berair yang sedang disipkan untuk sawah. Di lokasi penelitian ditemukan singkapan tembikar dan temuan fragmen keramik dalam jumlah yang relatif sedikit pada bidang area yang luas (Gambar 4).
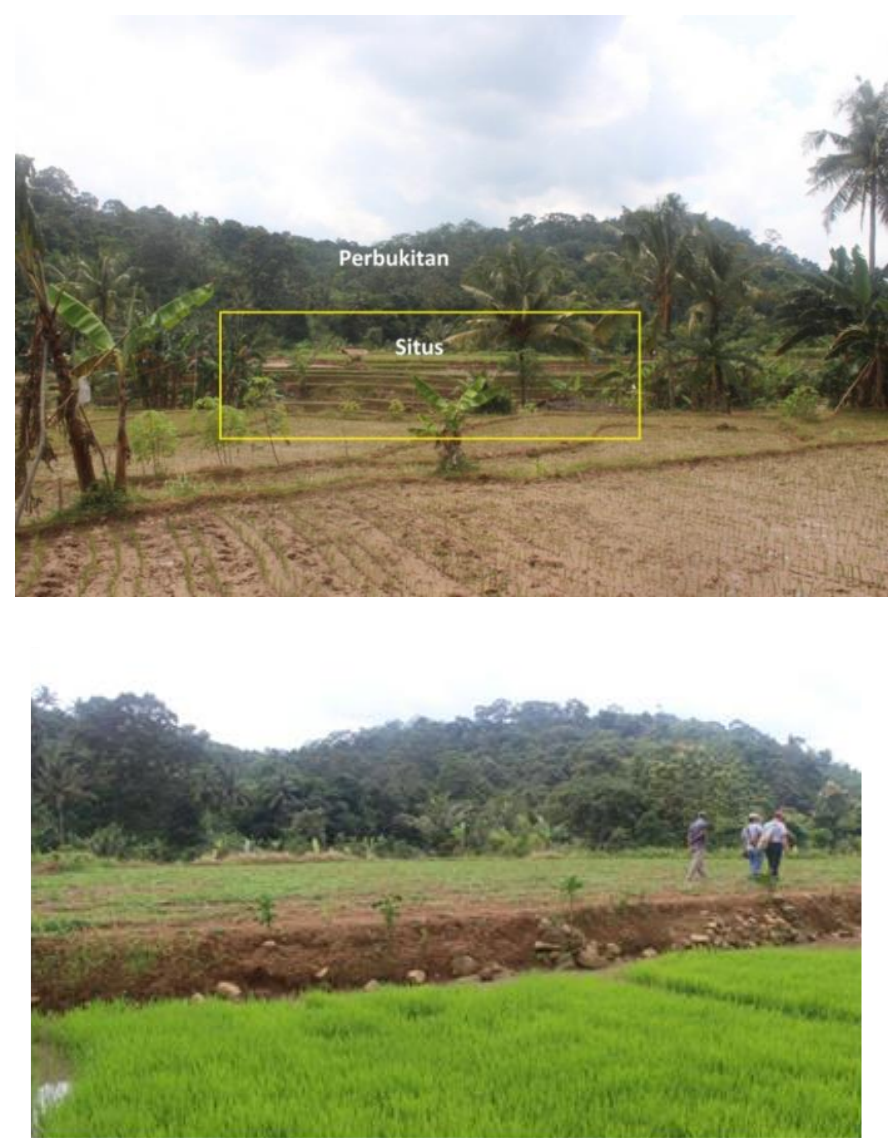

Gambar 2. Lahan situs yang lebih tinggi dari sekitar (Sumber: Dokumen Balai Arkeologi Jawa Barat, 2018)

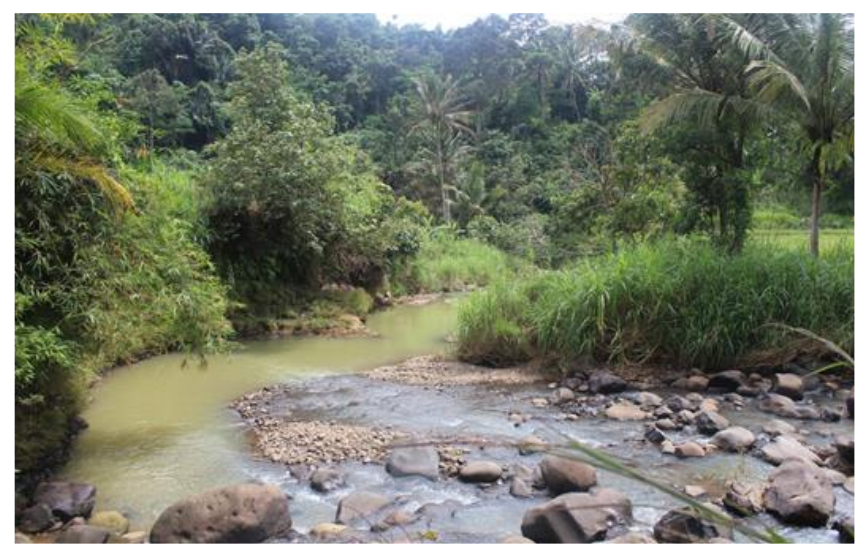

Gambar 3. Aliran Ci Teureup di selatan situs (Sumber: Dokumen Balai Arkeologi Jawa Barat, 2018). 

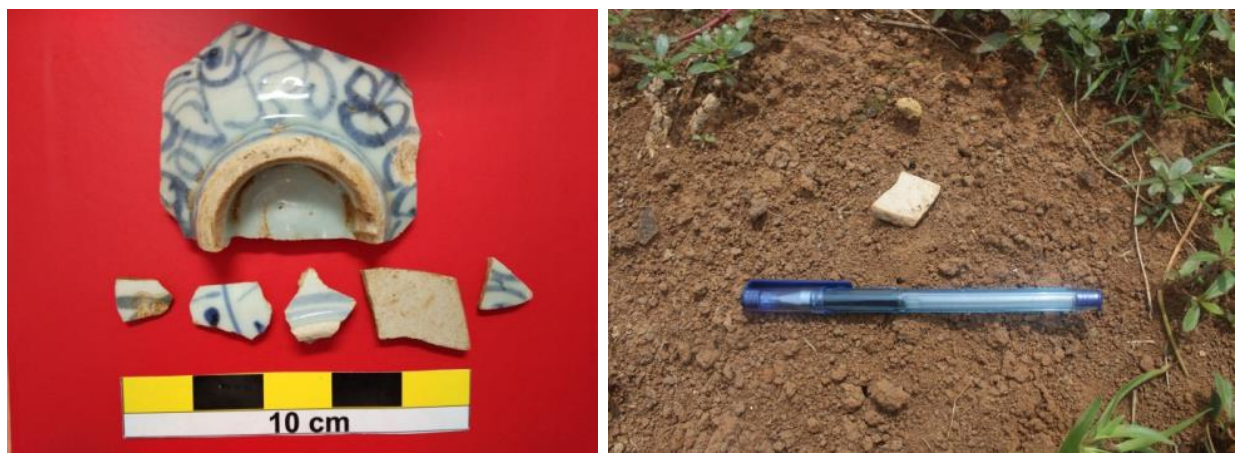

Gambar 4. Fragmen keramik Qing (19 M, fragmen paling besar-atas) dan fragmen keramik biru putih lainnya (bawah) di lokasi saat pengamatan lingkungan (Sumber: Dokumen Balai Arkeologi Jawa Barat, 2018).

Selain melakukan pengamatan terhadap lokasi temuan, penelitian juga dilakukan dengan melakukan analisis terhadap temuan artefak yang disimpan warga. Temuan diklasifikasikan menjadi 3 jenis, yaitu (1) keramik, (2) Logam, dan (3) tembikar. Berikut benda-benda yang ditemukan di situs Leuwiliang.

\section{Keramik}

Keramik yang ditemukan berupa satu guci, dua mangkuk, 6 fragmen badan dan 1 batu berwarna hijau, dan 7 fragmen keramik bagian badan berwarna coklat. Guci berukuran tinggi $50 \mathrm{~cm}$, diameter dasar $23 \mathrm{~cm}$, dan diameter tepian $18 \mathrm{~cm}$, dan diameter bagian badan guci $40 \mathrm{~cm}$. Guci berjenis stoneware (mengandung batuan, kasar), permukaan berwarna putih (glasir aus), dan bagian bawah berwarna kemerahan (Gambar 5). Terdapat 6 ornament pada bagian tepian dengan ketebalan tepian (rim) 1 $\mathrm{cm}$. Jejak glasir terlihat pada bagian dasar dalam guci berwarna hijau (celadon) kekuningan. Stoneware merupakan keramik yang dibakar dengan suhu tingi pada $1100-1400^{\circ} \mathrm{C}$ agar menghasilkan produk yang kuat, seperti kaca, dan tidak tembus air. Inovasi ini berasal dari Cina sejak awal masehi dan berkembang di wilayah daratan Asia lainnya seperti Jepang, Korea, dan negara-negara di Asian Tenggara seperti Thailand, Vietnam dan Laos (Peter Grave, 2009: 186).
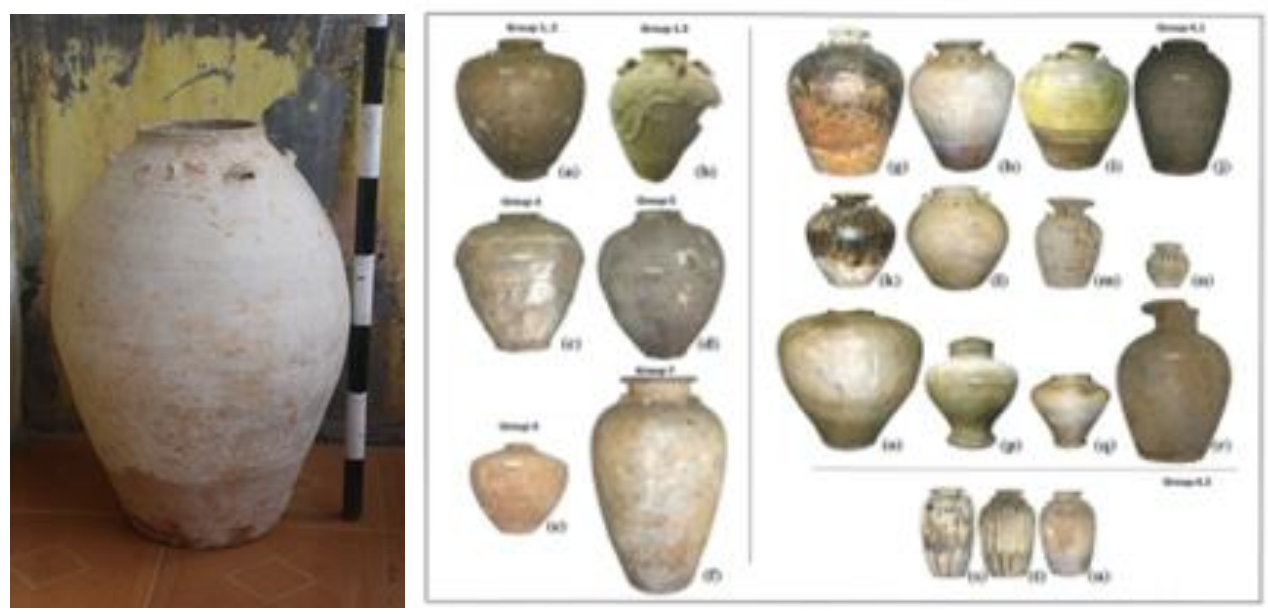

Gambar 5. Guci temuan Leuwiliang (kiri) dan varian guci stoneware di Asia (kanan)

(Sumber: Dokumen Balai Arkeologi Jawa Barat, 2018 dan Grave and Maccaroni, 2009: 197) 
Mangkuk yang ditemukan sebanyak 2 mangkuk. Mangkuk sebelumnya berupa pecahan atau fragmen yang direkatkan kembali. Mangkuk pertama memiliki diameter dasar $10 \mathrm{~cm}$, diameter tepian $21 \mathrm{~cm}$, tinggi $7 \mathrm{~cm}$, glasir hijau zaitun (celadon olive green) sedangkan mangkuk kedua mempunyai diameter dasar $10 \mathrm{~cm}$, diameter tepian 21 $\mathrm{cm}$, dan tinggi $7 \mathrm{~cm}$. Mangkuk berwarna abu-abu tanpa glasir. Keramik Cina abad ke-10 $\mathrm{M}$ dengan jejak berupa pointil dan goresan di dasar bagian dalam mangkuk merupakan jejak tumpukan mangkuk di atasnya pada saat pembakaran. (Gambar 6).
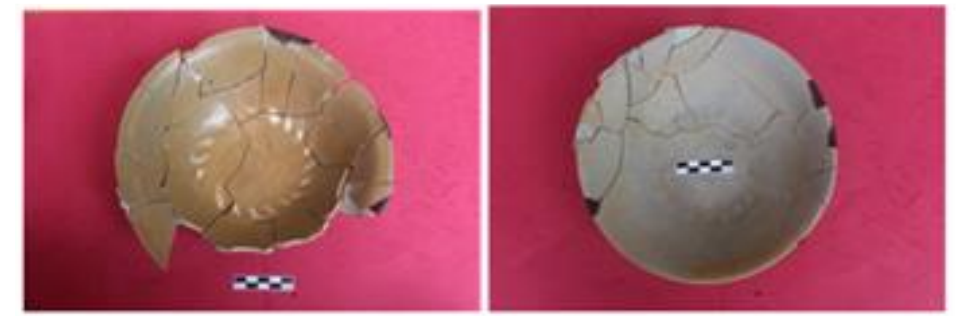

Gambar 6. Mangkuk Cina abad $10 \mathrm{M}$ berglasir hijau kecoklatan dan mangkuk tanpa glasir/aus tidak teridentifikasi (Sumber: Dokumen Balai Arkeologi Jawa Barat, 2018)

Fragmen keramik berjumlah 6 dengan varian yang berbeda dan 7 fragmen keramik bagian badan berglasir sama, yaitu coklat berasal dari Thailand (15 M). Fragmen keramik berjumlah 6 terdiri dari 3 fragmen dengan jejak motif biru putih, 2 fragmen polos, dan 1 fragmen dengan motif flora hitam bawah glasir (Vietnam abad 15 M). fragmen lainnya tidak teridentifikasi. Satu batu ditemukan berwarna hijau bercak coklat berdiameter, $5 \mathrm{~cm}$ (Gambar 7a-b).

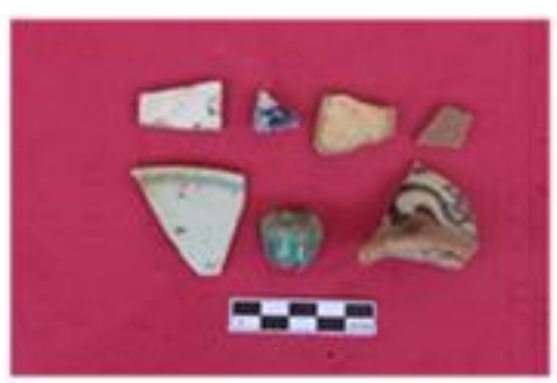

Gambar 7a. 6 Fragmen keramik dan batu hijau (Sumber: Dokumen Balai Arkeologi Jawa Barat, 2018)

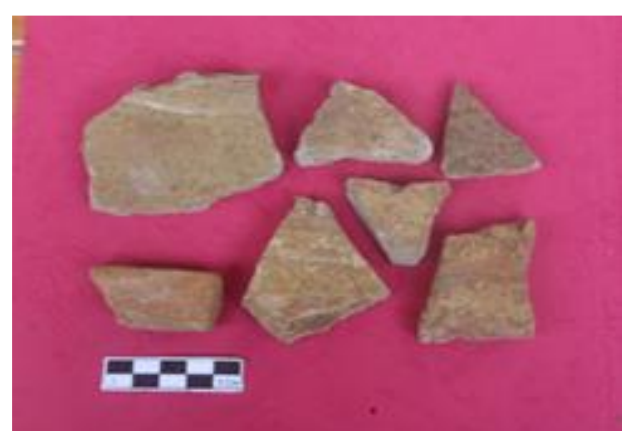

Gambar 7b. 7 fragmen keramik Thailand berglasir coklat, $15 \mathrm{M}$ (Sumber: Dokumen Balai Arkeologi Jawa Barat, 2018)

Guci memperlihatkan ciri keramik Thailand, Sawankhalok ware (15 M). Keramik buatan Sawankhalok populer pada abad 15 dan berlanjut hingga abad 16 M. Teknologi pembuatan keramik Thailand diadopsi dari Cina. Salah satu karakteristik keramik Thailand terbuat dari stoneware yang dibakar dengan suhu tinggi dan mengandung oksida besi yang tinggi (Rooney, 1990: 125--129). Keramik Thailand seringkali ditemukan bersamaan dengan keramik Vietnam dan Cina pada abad 15 M. 
Keramik Thailand biru bawah glasir ditemukan juga di wilayah Bogor, lebih tepatnya di dekat Situs Kebon Kopi dan Ciaruteun, Bogor. Banyaknya keramik Thailand yang ditemukan di Indonesia pada abad ke-15 M berkaitan dengan pengaruh Siam terhadap Malaka dan Singapura dan hanya sedikit daftar kapal-kapal Siam yang menuju wilayah Jawa pada abad ke-17 M. Baru pada akhir abad ke-17 M dan bersamaan dengan penguasaan VOC, kedatangan keramik Vietnam, Thailand, dan Cina semakin meningkat. H.W Woodward menyatakan produsen pengeksport keramik Thailand pada abad ke-15 M, yaitu kebanyakan dari Ayuthaya dan kiln-kiln (pabrik tembikar) di sekitar wilayah Satchalanai (Miksic, 1986: 232).

\section{Logam}

Temuan logam yang ditemukan terdiri dari: Genta, fragmen logam, wadah logam, dan spatula.

\section{a. Genta/lonceng}

Genta berasal dari bahasa sansekerta ghata yang berarti bel atau lonceng (Endang dalam Geria, 1999: 47). Genta atau lonceng merupakan salah satu alat atau perlengkapan upacara khususnya agama Hindu dan Buddha dan telah dikenal sejak masa klasik di Indonesia ( $8-15 \mathrm{M}$ ). Genta pada umumnya terbagi mejadi tiga bagian yaitu bagian bawah membulat, bagian tengah berupa lingkaran-lingkaran, dan bagian atas berupa hiasan-hiasan, yang paling populer adalah hiasan berbentuk vajra (sejata; tongkat logam dengan berbagai sula. Gambar genta ditemukan dalam relief di Candi Borobudur dan pada relief candi-candi lainnya, dan juga pada prasasti seperti Trunyan, Sukawana, Serai dan Bebetin (Goris, 1954 dalam Geria, 1999). Genta biasanya dipakai oleh pendeta dalam upacara bersama dengan vajra, keduanya menurut Endang Sri Hardiati melambangkan dualisme kosmos. I Gusti Ngurah Anom berpendapat pendeta itu sendiri adalah symbol dari mikrokosmos dan genta yang dipakai pendeta menurut Bennet Kempers adalah dualistis dari kosmos. Sebagai kosmos, genta dapat dibandingkan dengan stupa di dalam agama Buddha (Geria, 1999: 47--50).

Bahan genta yang ditemukan di Leuwiliang (Gambar 8) terbuat dari logam perunggu yang sudah berkarat dan terdapat noda patina (berwarna biru). Satu lonceng utuh, satu lonceng rusak pada bagian badannya, satu terdapat bandul pada bagian dalam, dan terakhir satu lonceng tanpa kait. Terdapat batang logam sebagai pelatuk bunyi di bagian dalam genta dan dua bulir logam yang diduga merupakan bandul pelatuk bunyi genta yang terpisah dari batangnya.
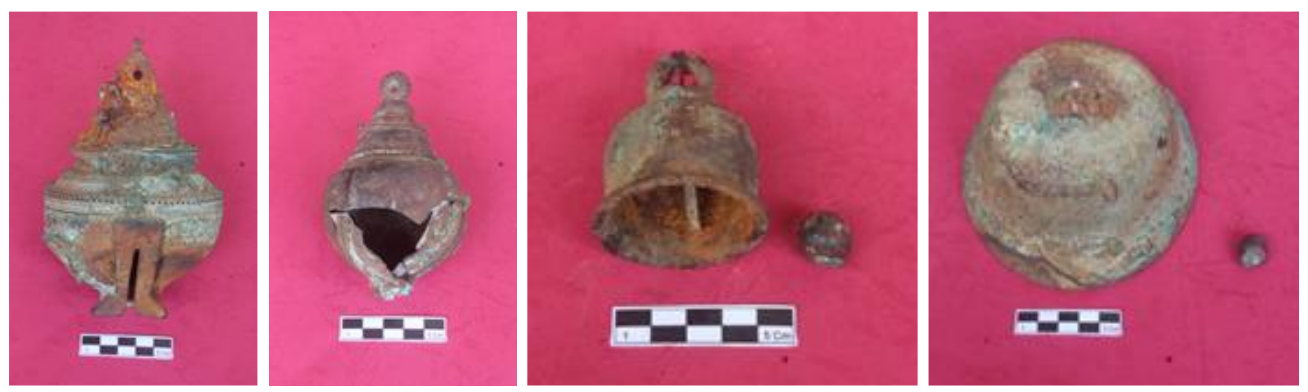

Gambar 8. Genta (Sumber: Dokumen Balai Arkeologi Jawa Barat, 2018) 
Meskipun terdapat ciri-ciri umum berupa tiga bagian dengan bagian atas atau puncak berupa hiasan senjata atau macam-macam bentuk vajra, secara khusus tidak semua genta sama. Di Bali jenis genta yang dipakai oleh golongan Brahmana berbeda dengan yang dipakai oleh golongan bujangga (Geria, 1999: 45--47). Temuan genta juga pernah ditemukan dalam penelitian arkeologis dan tersimpan dalam wadah, seperti halnya temuan di Leuwiliang ini yang disimpan di dalam guci. Temuan genta di Lamongan berada dalam kuali tanah liat yang sudah rusak. Temuan tersebut ditemukan ketika menggarap lahan oleh petani di tanah milik Purnomo di kedalaman sekitar $2 \mathrm{~m}$. Berikut bentuk genta yang ditemukan di lokasi lain (Gambar 9).

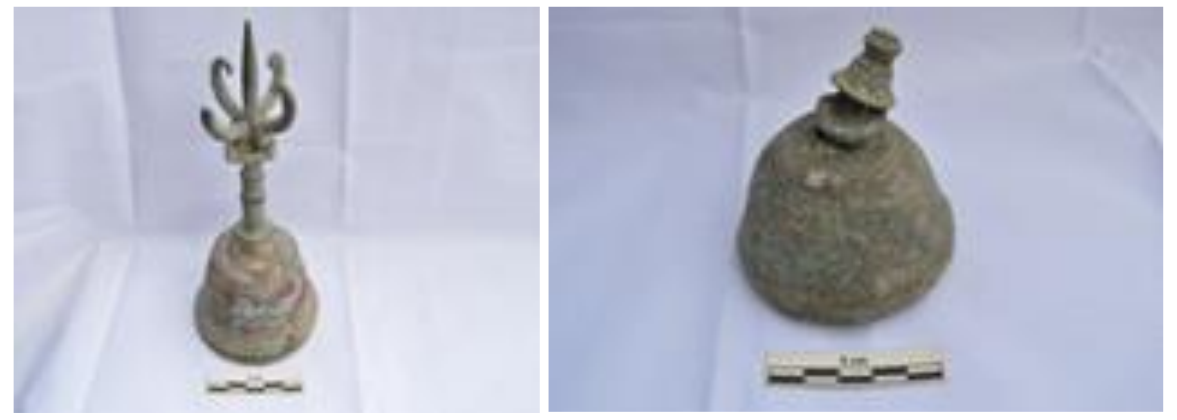

Gambar 9. Temuan genta di Dusun Plosogeneng, Desa Plosowahyu, Kecamatan Lamongan Kabupaten Lamongan (Sumber: Nastiti, 2014)

\section{b. Fragmen logam}

Fragmen logam yang ditemukan berupa; dua keping logam dengan bagian dasar rusak dan berlubang; tiga fragmen logam berbentuk setengah lingkaran yang patah; tiga fragmen batang logam berbentuk pipih, dan rantai dengan sembilan kait (Gambar 10). Temuan fragmen besi di atas masih belum diketahui bentuk utuh dan fungsinya kemungkinan merupakan bagian dari komponen suatu benda atau alat yang mengait dengan komponen lainnya mengingat terdapat lubang kecil dan bentuk pipih di ujung batang besi sedangkan fragmen lingkaran dan setengah lingkaran, diduga merupakan bagian dari sejenis wadah atau mangkuk kecil.
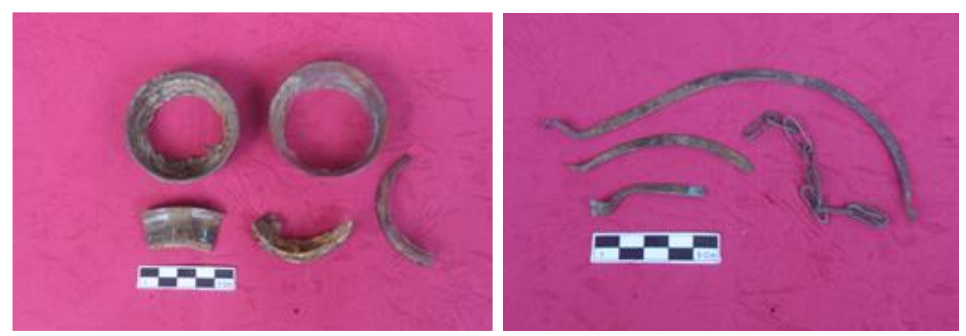

Gambar 10. Fragmen logam (Sumber: Dokumen Balai Arkeologi Jawa Barat, 2018)

c. Wadah logam

Wadah logam berbentuk mangkuk terbuat dari perunggu. Diameter wadah $12-$ $13,5 \mathrm{~cm}$, tinggi $3 \mathrm{~cm}$, dan diameter bagian atas $14,5 \mathrm{~cm}$. Wadah perunggu berjumlah tiga, satu wadah utuh, satu berlubang (rusak) di tengah, dan satu berlubang di tepian. Ketiga wadah diduga merupakan tatakan neraca/timbangan atau bisa juga lampu 
gantung seperti yang ditemukan di dalam periuk di Dusun Plosogeneng, Kecamatan Lamongan, Kabupaten Lamongan Jawa Timur (Titi Surti Nastiti, 2014:39) (Gambar 11a-b).

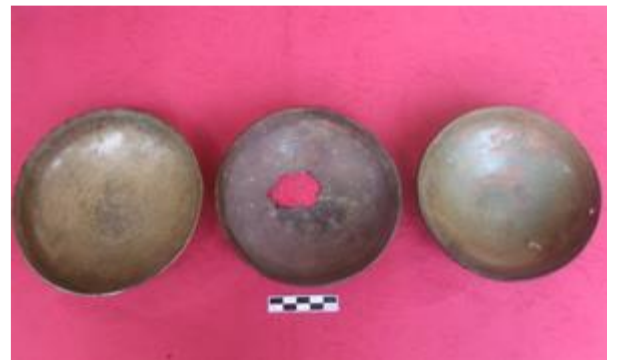

Gambar 11a. Fragmen wadah logam (Sumber: Dokumen Balai Arkeologi Jawa Barat, 2018)
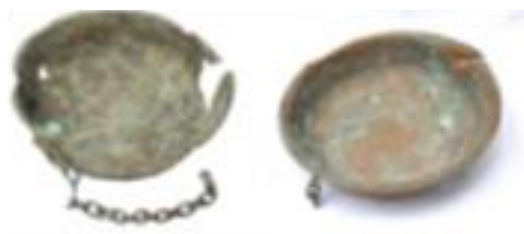

Gambar 11b. Lampu Gantung temuan di Lamongan (Sumber: Nastiti, 2014: 39)

\section{d. Spatula logam}

Spatula/fungsi sejenis sendok terbuat dari logam. Terdapat dua spatula, satu bertangkai pendek dan satu lagi bertangkai panjang. Spatula dengan tangkai pendek bagian wadah berupa lingkaran dengan diameter $13,5 \mathrm{~cm}$, dan panjang tangkai $10 \mathrm{~cm}$ dengan ujung melengkung sedangkan spatula bertangkai panjang berdiameter wadah berupa lingkaran $12 \mathrm{~cm}$ dan panjang tangkai $35 \mathrm{~cm}$ dengan ujung tumpul membulat (Gambar 12).
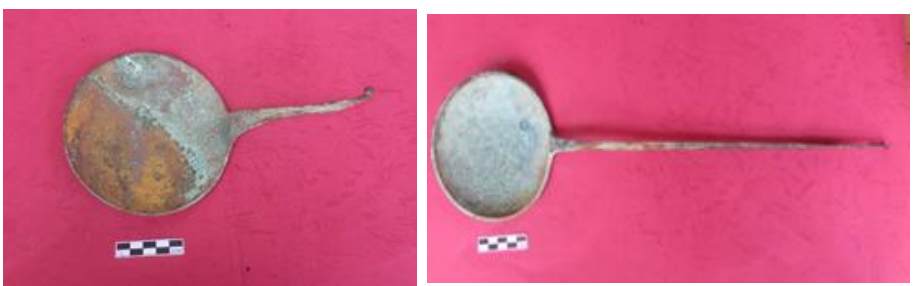

Gambar 12. Spatula (Sumber: Dokumen Balai Arkeologi Jawa Barat, 2018)

Temuan benda-benda logam ini mengingatkan dengan temuan logam yang ada di Situs Pasir Angin, Desa Cemplang Kecamatan Cibungbulang. Lokasi situs tersebut relatif berdekatan dengan Desa Barengkok, yaitu $5 \mathrm{~km}$ di sebelah utara dan berdekatan dengan aliran sungai yang sama, yaitu $\mathrm{Ci}$ Anten namun berbeda konteks perolehan temuannya. Di Situs Pasir Angin ditemukan benda logam yaitu kapak, tongkat, hiasan, lempengan, tombak, pedang, kerak besi, topeng dan gelang yang diperoleh melalui ekskavasi $15-45 \mathrm{~cm}$, dan $55-95 \mathrm{~cm}$. Hasil analisis metalografi artefak khususnya artefak perunggu Pasir Angin mengindikasikan adanya persamaan teknologi pembuatan dengan perunggu yang berasal dari Dongson sehingga diduga kronologi situs ini berasal dari masa perundagian (Prijono, 2016: 78).

\section{Fragmen tembikar}

Fragmen tembikar yang ditemukan berjumlah 9 fragmen bagian badan. 4 fragmen berwarna hitam sedangkan 4 lainnya berwarna coklat dengan bagian dalam 
berwarna hitam tanda pembakaran yang tidak sempurna. Tekstur tembikar kasar dan tanpa glasir. Butiran pasir sebagai bahan campuran (temper) terlihat di permukaan. Tembikar ditemukan tanpa motif/polos. Ukuran tembikar relatif kecil, dengan panjang fragmen 3-6 cm dan ketebalan 0, 5-1 cm. fragmen tembikar sulit diidentifikasi karena semuanya berupa frgamen bagian badan sehingga tidak diketahui perihal diameternya yang berkaitan dengan ukuran, volume sebagai salah satu indikator untuk mengetahui perihal perkiraan bentuk dan kemudian fungsinya. Rekonstruksi bentuk tembikar dapat dilakukan setidaknya dengan ketersediaan bagian tepian (rim/edge) dan dasar (base).

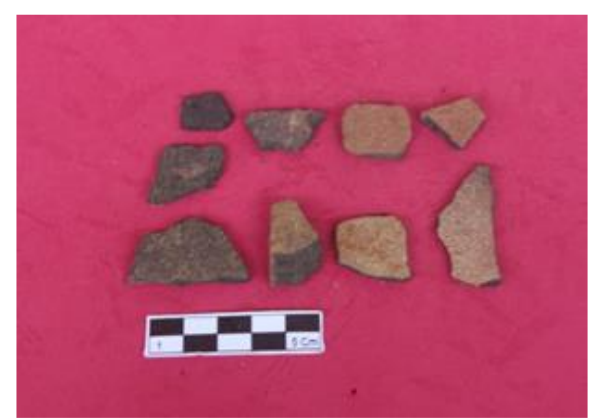

Gambar 13. Fragmen wadah tembikar

(Sumber: Dokumen Balai Arkeologi Jawa Barat, 2018)

Berdasarkan wawancara, lokasi temuan guci dan benda-benda yang ada di dalamnya berada di sebelah barat rumah Ace, di tengah areal persawahan. Kontur di wilayah ini berupa tanah datar dan tanah turunan bersusun seperti bentukan terasering Ci Teureup di bagian selatan dari lokasi temuan guci. Areal ini secara keluasan dikelilingi perbukitan terutama di sebelah selatan. Berikut peta lokasi temuan tersebut. Tata letak temuan tersebut berada dekat dengan sumber air atau sungai. Pola ini umum dijumpai pada situs-situs arkeologi. Di Bogor, lokasi Leuwiliang berdekatan dengan lokasi situs Ciampea. Kedua situs tersebut dialiri anak-anak Ci Anten dan berada di utara Gunung Salak.
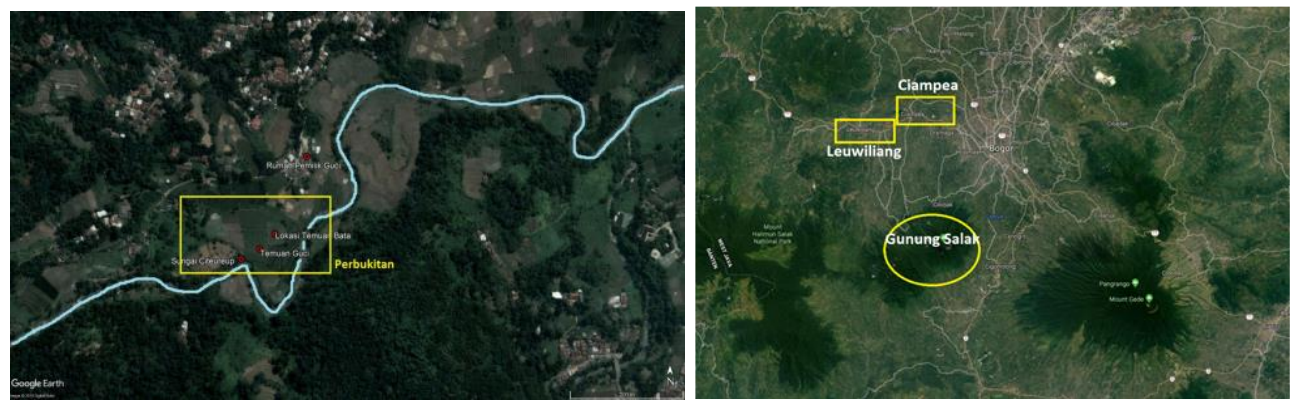

Gambar 14. Lokasi temuan guci (Sumber: Google Earth dengan penyesuaian)

Keseluruhan data yang telah terkumpul yaitu data lingkungan dan artefak diketahui dua pokok bahasan yang perlu dicermati berkaitan dengan identifikasi awal situs Leuwiliang, yaitu 
(1) Berdasarkan analisis awal dan hasil peninjauan diketahui bahwa bendabenda yang ditemukan di Desa Barengkok adalah benda-benda arkeologis (kuno). Benda-benda tersebut berada di dalam guci dengan kualitas yang tidak terlalu baik dengan glasir yang sudah aus dan diduga berasal dari Sawankhalok, Thailand abad ke$15 \mathrm{M}$. Jenis-jenis benda diketahui merupakan logam berupa genta (lonceng), dan sejenis peralatan untuk mengolah besi. Kondisi lonceng relatif utuh dan satu rusak selain lonceng terdapat pula fragmen dan wadah logam lainnya, dan fragmen keramik dengan kronologi tua (10 M) dan muda (19 M). Ditemukannya benda-benda tersebut dalam satu wadah guci mengindikasikan adanya kesengajaan untuk menyimpan bendabenda tersebut dalam suatu wadah dan kemudian dikuburkan di dalam tanah. Dilihat dari varian kronologi relatif keramik yang tergolong berbeda-beda abad yang jauh, benda-benda tersebut diduga sebagai koleksi yang kemudian disimpan di dalam guci lalu dikuburkan. Hal ini berbeda dengan konteks bekal kubur karena konteksnya masih belum jelas.

Benda-benda arkeologi yang terkubur biasanya mempunyai arti tertentu. Secara garis besar bisa bermakna hal yang umum (profan), adapula yang bermakna khusus yang berkaitan dengan religiusitas (sakral). Penentuan sakral atau profan ini berkaitan dengan konteks situs atau lokasi tempat benda-benda arkeologi saat ditemukan.

Berdasarkan lokasi temuannya terlihat tidak banyak artefak penyerta lainnya yang mendukung pada kecurigaan tertentu yang spesifik atau mengarah kepada fungsi situs. Jejak sisa bata yang diinformasikan saat ini sudah tertutup sawah sehingga tidak didapat foto yang akurat pun pada singkapan artefak lainnya yang tidak terlalu banyak terlihat. Secara kecenderungan, kualitas benda yang ditemukan merupakan ciri dari benda kuno tetapi dalam segi kuantitas temuan, tidak signifikan pada areal yang luas.

(2) Berdasarkan pengamatan bentang lahan terlihat adanya pola yang sama dengan bentang lahan kawasan Ciampea dan sekitarnya, yaitu kedua lokasi berada di utara Gunung Salak dan berdekatan dengan alian sungai yang saling terkoneksi. Ci Anten jika dikaitkan dengan lokasi situs-situs arkeologi di Bogor seperti Ciaruteun dan Pasir Angin merupakan sungai yang potensial sebagai poros sebaran data arkeologis, termasuk juga sungai yang melintasi Desa Barengkok. Diketahui bahwa morfologi situs-situs di Indonesia seringkali ditemukan berdekatan dengan sumber air dan gunung sebagai orientasinya. Ciri umum tersebut tampak pada lokasi temuan guci di Desa Barengkok meskipun jenis aktivitas masa lampau yang dimaksud belum dapat dipastikan mengingat masih minimnya bukti-bukti artefaktual yang ada sehingga membutuhkan penelitian lebih lanjut. Potensi ini masih terbuka lebar mengingat penelusuran data dan sejarah arkeologi klasik di Jawa bagian barat masih bersifat fragmentaris dan mengalami kekosongan politis antara 686-932 (Saptono, 2003: 35).

\section{SIMPULAN}

Berdasarkan peninjauan awal dan analisis temuan guci di Desa Barengkok mengindikasikan adanya aktivitas manusia masa lampau yang menyimpan benda-benda tersebut ke dalam guci dan menguburkannya. Lokasi penguburan diketahui memiliki 
kesesuaian dengan ciri-ciri umum pemilihan lokasi beraktivitas manusia masa lampau (situs) yang berdekatan dengan sumber air dan berorientasi dengan gunung. Meskipun dari segi lokasi mendukung sebagai ciri situs tetapi dari segi artefak masih sangat minim untuk mengacu pada simpulan fungsi situs yang spesifik. Simpulan analisis ini mengerucut pada hasil bahwa di Desa Barengkok terdapat potensi situs arkeologi yang datanya masih harus diverifikasi kembali karena kualitas dan kuantitas informasinya yang masih sangat minim. Berdasarkan kondisi tersebut di atas dan mengingat temuan di wilayah tesebut belum diketahui secara maksimal, maka saran yang dapat dilakukan ke depan, yaitu:

1. Survei area potensi situs: geomorfologi, geologi, georadar

2. Pemetaan dan penggambaran detail denah situs

3. Pembukaan lubang uji di beberapa titik dan pengambilan sample dating (jika ada)

4. Studi bandingan dengan Situs Ciampea, Pasir Angin, dan sekitarnya

5. Penanganan temuan berupa inventarisasi dan pemeliharaan yang bersinergi dengan pemerintah setempat.

\section{UCAPAN TERIMA KASIH}

Penulis berterima kasih kepada Tim Penelitian peninjauan kasus Temuan Guci di Leuwiliang, Bogor; Dr. Lutfi Yondri, M. Hum, Oerip Bramantyo Boedi, S.S., M. Hum dan Dra. Desril Riva Shanti.

\section{DAFTAR PUSTAKA}

Geria, I. M. (1999). Temuan Genta Perunggu di Desa Manistutu Negara. Forum Arkeologi, II.

Miksic, J. N. (1986). Thai and Vietnamese Pottery in Indonesia and Fifteenth-Century Trade in Southeast Asia IIIa Aspek Sosial-Budaya. In Pertemuan Ilmiah Arkeologi IV (pp. 119--237). Jakarta: Pusat Penelitian Arkeologi Nasional Departemen Pendidikan dan Kebudayaan.

Mundardjito. (2002). Pertimbangan Ekologis Penempatan Situs Masa Hindu Bddha di Daerah Yogyakarta. Jakarta: EFEO dan WWS.

Nurwani Citra. (2010). Geologi Daerah Ciampea-Leuwiliang, Kabupaten Bogor, Jawa Barat Tugas Akhir A - PDF. ITB.

Peter Grave, M. M. (2009). Characterizing Asian Stoneware Jar Production at the Transition to the Early Modern Period 1550--1650. In Scientific Research on Asian Ceramics. Proceedings of the Fourth Forbes Symposium at the Freer Gallery of Art. Washington DC USA.

Poesponegoro, M. D. N. N. (1993). Sejarah Nasional Indonesia II. (B. Sumadio, Ed.) (4th ed.). Jakarta: Balai Pustaka.

Prijono, S. (2016). Artefak Prasejarah Perunggu Prasejarah Situs Pasir Angin Bogor: Hubungannya dengan Aspek Sumber Bahan. Berkala Arkeologi, Vol.36 (No. 1 Mei), 71-82.

Rooney, D. F. (1990). A Field Guide to Glazed Thai Ceramics. Asian Perspectives. 
University of Hawaii Press, 8 (No. 2).

Saptono, N. (2003). Rekontemplasi Arkeologi Klasik Jawa Barat. In E. S. Hardiati (Ed.), Nuansa arkeologi 2: Analisis Data dan Kebijakan (pp. 29-39). Bandung: Ikatan Ahli Arkeologi Indonesia Komda Jabar Banten.

Simamora, A. B. (2013). Perencanaan Lanskap Desa Barengkok Kecamatan Leuwiliang Kabupaten Bogor menuju Kawasan Agrowisata.

Titi Surti Nastiti. (2014). Eksplorasi Peninggalan Kerajaan Mataram Kuno di Jawa Timur (Abad 10--11 M) di Kabupaten Lamongan Provinsi Jawa Timur. Jakarta.

Widyastuti, E. (2010). Laporan Penelitian Permukiman Klasik di Kabupaten Bogor. Bandung. 
JURNAL PANALUNGTIK - Vol. 2, No. 2, Desember 2019 